\title{
Human and livestock faecal biomarkers at the prehistorical encampment site of Ullafelsen in the Fotsch Valley, Stubai Alps, Austria - potential and limitations
}

Marcel Lerch ${ }^{1,2}$, Tobias Bromm², Clemens Geitner ${ }^{3}$, Jean Nicolas Haas ${ }^{4}$, Dieter Schäfer ${ }^{5}$, Bruno Glaser ${ }^{2}$,

Michael Zech ${ }^{1,2}$

${ }^{1}$ Heisenberg Chair of Physical Geography with focus on paleoenvironmental research, Department of Geosciences, Technische Universität Dresden, Helmholtzstraße 10, 01096 Dresden, Germany

${ }^{2}$ Soil Biogeochemistry Group, Institute of Agricultural and Nutritional Sciences, Martin-Luther University Halle-Wittenberg,

10 Von-Seckendorff-Platz 3, D-06120, Halle (Saale), Germany

${ }^{3}$ Institute of Geography, University of Innsbruck, Innrain 52f, A-6020 Innsbruck, Austria

${ }^{4}$ Institute of Botany, University of Innsbruck, Sternwartestraße 15, A-6020 Innsbruck, Austria

${ }^{5}$ Institute of Geology, University of Innsbruck, Innrain 52f, A-6020 Innsbruck, Austria

Correspondence to: Marcel Lerch (marcel.lerch@tu-dresden.de)

15 Abstract. The Ullafelsen at $1869 \mathrm{~m}$ a.s.1. in the Tyrolean Stubai Alps next to Innsbruck is an important (geo-)archaeological reference site for the Mesolithic period. Buried fireplaces on the Ullafelsen plateau were dated at 10.9 - 9.5 cal. kyrs BP and demonstrate together with thousands of flint stone artifacts the presence of hunter-gatherers during the Early Holocene. Most recently, we demonstrated the great potential of $n$-alkane and black carbon biomarkers for contributing to a better understanding of pedogenesis and landscape evolution. In order to study the importance of human and/or animals for occupation of this relevant geoarchaeological site, we carried out steroid and bile acid analyses on two modern faeces samples from cattle and sheep and on 37 soil samples from seven soil profiles at the Ullafelsen. The modern animal faeces show a dominance of $5 \beta$-stigmastanol and deoxycholic acid for ruminants (cattle and sheep), which is in agreement with literature data. The OAh horizons, which have accumulated and developed since the Mesolithic, revealed high contents of steroids and bile acids; the E (LL) horizon coinciding with the Mesolithic living floor is characterized by medium contents of steroids and bile acids. By contrast, the subsoil horizons $\mathrm{Bh}, \mathrm{Bs}$ and $\mathrm{BvCv}$ contain low contents of faecal biomarkers indicating that leaching of steroids and bile acids into the podsolic subsoils is not an important factor. Deoxycholic acid is the most abundant bile acid in all soil samples and gives evidence for strong faeces input of ruminants. The steroid and bile acid patterns and ratios indicate a negligible input of human faeces on the Ullafelsen. $\beta$-Sitosterol as plant-derived steroid has also a strong influence on the faecal biomarker pattern in our soils. Root input into the subsoils is likely reflected by $\beta$-sitosterol contents. In conclusion, our results reflect a strong faecal input by livestock, rather than by humans as found for other Anthrosols such as Amazonian Dark Earths. Further studies need to focus on the question of the exact timing of faeces deposition.

Keywords. Animal faeces, Steroids, Bile acids, Mesolithic, Neolithic, Prehistorical animal husbandry, Anthrosol, Geoarchaeology 
https://doi.org/10.5194/bg-2021-186

Preprint. Discussion started: 22 July 2021

(c) Author(s) 2021. CC BY 4.0 License.

(c) (i)

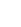

\section{Introduction}

35 Archaeological research in high mountain regions received increasing attention during the last decades. Based on the finding of the copper age mummy called "Ötzi" at the Tisenjoch in the Ötztaler Alps in 1991, archaeological research projects were also launched in the Central Alps (Schäfer, 2011b). Accordingly, Mesolithic hunter-gatherers lived in the Alpine regions since the beginning of the Holocene (Fontana et al., 2016). For instance, Schäfer et al. (2016) and Cornelissen and Reitmaier (2016) provided evidence for the presence of Mesolithic people at the upper subalpine or alpine zones in the central and south-eastern

40 Swiss Alps.

Concerning the Tyrolean Alps, the Mesolithic site of Ullafelsen (1869 m a.s.l.) in the Fotsch Valley was discovered by the archaeologist Dieter Schäfer in 1994 and became an important archaeological reference site (Schäfer, 2011a, 2011b) (Figs.1 and 2). At this site, thousands of archaeological artifacts and many buried fireplaces were found. This provides clear evidence for the presence and the human environment interaction of our ancestors (Schäfer, 2011a, 2011b). Previous archaeological

45 research demonstrates that the Ullafelsen was used as a summer camp by Mesolithic hunter-gatherers during the Preboreal and Boreal from around 10.9 to 9.5 kyrs BP (Schäfer, 2011a).

\section{- Figure 1 -}

50 From a pedological point of view, a striking and frequently occurring light layer (LL) below the topsoils was described for the Ullafelsen and was a focus of previous investigations (Geitner et al., 2011; Geitner and Schäfer, 2010; Geitner et al., 2014). Similar light horizons are typical for soils developed in the subalpine zone of the Central Alps and are usually interpreted as eluvial horizons (E) horizons of podzols (Zech and Wilke, 1977; Egli et al., 2008), or as eventual loess deposit (Geitner et al., 2011; Schäfer, 2011a). At the Ullafelsen, most artifacts and Mesolithic fire places were found within and directly on the top

55 of the E (LL) horizon (Schäfer, 2011a). Therefore, the E (LL) horizon is regarded as Mesolithic living floor, the humic-rich subsoil below the E (LL) horizon was considered as Late Glacial buried former topsoil (2Ahb horizon) (Schäfer, 2011a; Geitner et al., 2011).

Recently, black carbon results based on benzene polycarboxylic acid analyses corroborated fire-induced human impact on the $\mathrm{E}$ (LL) horizon. The absence of leaf wax-derived $n$-alkane biomarkers in the subsoils together with the absence of Late Glacial

60 radiocarbon ages challenge the existence of a Late Glacial buried topsoil (2Ahb horizon) and rather point to a humus-enriched podzolic Bh horizon (Zech et al., 2021).

In the context of alpine pastoralism (grazing, dairying) since the Neolithic period in different parts of the Alps, (cattle)husbandry and agriculture became increasingly important for human society (Reitmaier et al., 2018; Gilck and Poschlod, 2019). Grazing livestock such as cattle and sheep have been a predominant anthropozoological impact for the 65 Ullafelsen and surroundings presumably since the Bronze Age (4.2-2.8 kyrs. BP) (Zech et al., 2021). 
https://doi.org/10.5194/bg-2021-186

Preprint. Discussion started: 22 July 2021

(c) Author(s) 2021. CC BY 4.0 License.

(c) (i)

Faecal biomarker analyses have become an attractive tool in palaeoenvironmental and archaeological research during the last decades (Baeten et al., 2012; Prost et al., 2017; Glaser and Birk, 2012). The respective molecules are considered as diagnostic markers for detecting ancient faecal inputs in soils (Bull et al., 1999b), whereby steroids and bile acids are the relevant compound classes (Bull et al., 2005). These provide insights into ancient agricultural practices and the former presence of

70 animals or humans (Prost et al., 2017).

Previous studies prove the specific steroid and bile acid signals for various organisms (Bull et al., 2005; Birk et al., 2011; Prost et al., 2017; Haurrault et al., 2019). Accordingly, faecal biomarker analyses allow to distinguish between faeces of herbivores, pigs and humans as well as their residues in soils and sediments (Haurrault et al., 2019; Lühe et al., 2013). However, plants show also a specific steroid signal, which has to be considered during interpretations (Evershed et al., 1997; Hartmann, 1998).

75 A finer differentiation between faeces of different livestock can be achieved by the combination of several steroids $\left(\Delta^{5}\right.$-sterols,

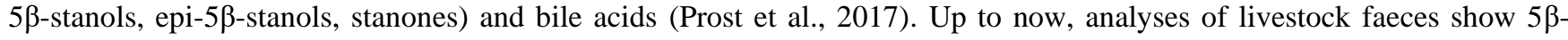
stigmastanol as the dominant steroid compound for ruminants (cattle and sheep), whereas coprostanol is a marker for omnivores such as humans and pigs (Prost et al., 2017; Haurrault et al., 2019; Glaser and Birk, 2012). In contrast, plants contain high amounts of $\beta$-sitosterol and stigmasterol ( $\Delta^{5}$-sterols), which have also been detected in roots and litter (Piironen et al.,

80 2000; Verma and Gupta, 2013).

Steroids have a low water solubility and are thus not leached into deeper soil horizons (Bull et al., 2002; Prost et al., 2017). Faecal steroids and bile acids as organic compounds can accumulate and persist in sediments and soils for more than thousands of years (Bull et al., 2001). The 5 $\beta$-stanols coprostanol and 5 $\beta$-stigmastanol are products of anaerobic microbial reduction of $\Delta^{5}$-sterols such as cholesterol or $\beta$-sitosterol (Schroeter et al., 2020). In mammals, this reduction is performed by gut bacteria

85 and results in different ratios of $5 \beta$-stanols depending on food intake (Bull et al., 1999a). Epimerization of $5 \beta$-stanols, which occurs in soils due to microbial and diagenetic transformation, has to be considered when applying steroid ratios (Bull et al., 1999a; Lühe et al., 2018).

Secondary bile acids are transformed microbially in the gut of mammals from primary bile acids (e. g. cholic acid or chenodeoxycholic acid), which are formed firstly in the liver from cholesterol (Bull et al., 2002; Kuhajda et al., 2006). Human

90 faeces show high abundance of lithocholic acid, whereas ruminant faeces have a dominance of deoxycholic acid (Prost et al., 2017; Shillito et al., 2020). Hence, steroids in combination with bile acids can be useful markers for reconstructing settlement history of a site based on past faecal inputs.

Faecal biomarkers are currently used in various scientific disciplines all over the world. Glaser et al. (2001), Glaser and Birk (2012) and Wiedner et al. (2015) investigated Anthropogenic Dark Earths, also known as terra preta de Índio, in Central

95 Amazonia. By applying steroid markers, they provided evidence for settlement activities in this part of the tropical rainforest. High nutrient contents induced by the deposition of human and animal faeces clearly demonstrated the anthropogenic origin of terra preta de Índio (Birk et al., 2011; Birk et al., 2012; Glaser and Birk, 2012). Another study used steroids and bile acids for identification of temporary mass graves of concentration camp prisoners at the end of World War II (Lühe et al., 2020). 
https://doi.org/10.5194/bg-2021-186

Preprint. Discussion started: 22 July 2021

(c) Author(s) 2021. CC BY 4.0 License.

Findings revealed elevated faecal steroid contents and thus corroborate the former input of human decomposition products as

well as faecal and tissue constituents of buried bodies (Lühe et al., 2020).

The aim of our here presented geoarchaeological study was to contribute to a better understanding of human and livestock impact at the prehistorical encampment site of Ullafelsen with the use of faecal biomarkers. More specifically, the following questions are addressed: (i) Do faecal biomarker patterns of modern ruminant faeces around the Ullafelsen reflect the steroid and bile acid patterns reported in literature and is a clear distinction from human faecal biomarker patterns possible? (ii) Do the steroid and bile acid contents and patterns of the soil profiles at the Ullafelsen allow discrimination between human and animal faecal input? (iii) Do the faecal biomarker patterns and ratios of the soil profiles on the Ullafelsen allow the reconstruction of the faecal input history during the Holocene?

\section{Material and Methods}

\subsection{Study area: The Ullafelsen as prehistorical encampment site in the Fotsch Valley, Stubai Alps, Austria}

110 The prehistorical encampment site of Ullafelsen, also called "Riegelschrofen", is located in the Fotsch Valley at an altitude of $1869 \mathrm{~m}$ a.s.l. The $13 \mathrm{~km}$ long Fotsch Valley belongs to the Stubaier Alps southwest of Innsbruck, the capital of the Austrian state Tyrol. The Ullafelsen is a round hump at the eastern site of the Fotsch Valley and is located in the subalpine vegetation zone (Fig. 1). This rock ledge lies $40 \mathrm{~m}$ above the level of the adjacent creek, called "Fotscherbach" (Schäfer, 2011a). The geographic coordinates of the archaeological excavation area at the Ullafelsen are N $47.14702^{\circ}$, E $11.21475^{\circ}$ (WGS84).

115 As a part of the transition zone between the wetter Northern and the drier Central Alps, our study area is characterized by a temperate climate with a mean annual temperature of $10^{\circ} \mathrm{C}$ in the summertime (July) and $-3^{\circ} \mathrm{C}$ in the wintertime (January). The mean annual precipitation is approx. $1500 \mathrm{~mm}$ (Schäfer, 2011a; Schlosser, 2011).

The vegetation is predominated by Swiss stone pine (Pinus cembra) and Juniper (Juniperus communis ssp. alpina). Furthermore, there are scattered Larch (Larix decidua), Norway spruce (Picea abies), Green alder (Alnus viridis) and Birch

120 (Betula pendula). Alpine rose (Rhododendron ferrugineum), Lingonberry (Vaccinium vitis-idaea), European blueberry (Vaccinium myrtillus) and Ling heather (Calluna vulgaris) are occurring as alpine dwarf shrubs. The vegetation cover also consists of several herbs and grasses (Kemmer, 2011; Zech et al., 2021).

From a geological point of view, the Fotsch Valley represents a part of the "Öztal-Stubai-cristalline-complex". Typical rocks for this study area are the metamorphic rocks mica slate and paragneiss. In addition, there also exist a variety of unconsolidated

125 quaternary sediments (Nittel, 2011). The basic material under the anthropogenically-influenced soils at the Ullafelsen consists, amongst others, of weathered till (Nittel, 2011). Despite human influence, these soils were mainly formed by podsolization during the Holocene (Zech et al., 2021). Typical soils in the alpine and subalpine zone of the Fotsch Valley are Cambisols and Leptosols. Under alpine dwarf shrub vegetation, Podzols have frequently developed, whereas in flatter valley floors and on some slope positions also Histosols can be found (Geitner et al., 2014). 
https://doi.org/10.5194/bg-2021-186

Preprint. Discussion started: 22 July 2021

(c) Author(s) 2021. CC BY 4.0 License.

(c) (i)

\section{$130 \quad$ 2.2 Sampling of modern faeces and archaeological soil profiles}

As part of fieldwork in July and August 2017, we collected 37 soil samples from seven profile walls of soil profiles at the Ullafelsen and two faeces samples from cattle and sheep (Table 1). Four profile walls are directly from the archaeological excavation area $(1.1 \mathrm{C} 4 \mathrm{w}, 1.1 \mathrm{~B} 5 \mathrm{~s}, 1.1 \mathrm{~B} 5 \mathrm{w}, 1.1 \mathrm{G} 5 \mathrm{n})$. Three profile walls are from a close-by trench (1.9 NW, $1.9 \mathrm{NE}, 1.9$ SW) (Fig. 2). The latter is located 2 meters below the archaeological excavation area at an altitude of approximately $1867 \mathrm{~m}$

135 a.s.l. Sampling was conducted by soil horizons, which were classified according to the WRB (IUSS Working Group WRB, 2015).

- Figure 2 -

140 For data evaluation, all 37 soil samples were sorted by horizons ( $n=37)$ : OAh1 $(n=6)$, OAh2 (n=4), OAh3 ( $n=3), E(L L)(n=8)$, $\mathrm{Bh}(\mathrm{n}=6), \mathrm{Bs}(\mathrm{n}=5), \mathrm{BvCv}(\mathrm{n}=5)$. Zech et al. (2021) carried out TOC and TOC/N analyses for these soil samples. Figure 3 illustrates the soil profile 1.9 NW with the horizons OAh1-OAh2-OAh3-E(LL)-Bh-Bs-BvCv. All other investigated soil profiles have a similar sequence of horizons. Results of grain size analyses for the soil profiles at the Ullafelsen show a dominance of sand (Geitner et al., 2011). In comparison to the other soil horizons, the E (LL) horizon is characterized by

145 remarkably higher amounts of silt (Geitner et al., 2011).

- Figure 3 -

The TOC values of the investigated soil samples range from 0.3 to $28.8 \%$ (Table 1 ). The maximum TOC content was observed in the OAh3 horizon, being in accordance with darker color and higher density of charcoal particles. Total nitrogen contents of the investigated soil profiles range from 0.0 to $1.2 \%$. The TOC/N ratios range from 12.4 to 37.2 with the highest ratios in the OAh3 horizon coinciding with charcoal particles in this soil horizon, related to former fireplaces, and high amounts of other organic material (Zech et al., 2021). High TOC/N ratios in the Bh horizons reflect podsolization processes (Zech et al., 2014; Glaser and Birk, 2012).

155 Radiocarbon-dated Mesolithic charcoal yielded ${ }^{14} \mathrm{C}$ ages ranging from 10.9 to 9.5 cal. kyrs BP (Schäfer, 2011a). More recently, Zech et al. (2021) yielded ${ }^{14} \mathrm{C}$ ages for bulk $n$-alkanes ranging from 8.2 to 4.9 cal. kyrs BP. This discrepancy suggests that a $n$ alkane producing vegetation cover, consisting of herbs, grasses and alpine dwarf-shrubs, did not predominate immediately after the Mesolithic abandonment. Rather, it must be assumed that non- $n$-alkane producing conifers, such as Pinus cembra or Picea abies, predominated the vegetation cover after the Mesolithic life on the Ullafelsen (Zech et al., 2021).

160 In addition to the 37 soil samples at the archaeological site, we analyzed 2 mixed faeces samples from cattle and sheep, which belong to the typical livestock at the Ullafelsen and surroundings. TOC contents of cattle and sheep range from 42.6 to 43.5 $\%$ (Table 1). 
https://doi.org/10.5194/bg-2021-186

Preprint. Discussion started: 22 July 2021

(c) Author(s) 2021. CC BY 4.0 License.

\section{(c) (i)}

\subsection{Faecal biomarker analyses}

Firstly, all soil and faeces samples were air-dried, sieved $(<2 \mathrm{~mm})$ and finely ground. Using an elemental analyzer coupled to an isotope ratio mass spectrometer (EA-IRMS), total carbon (TC) and total nitrogen (TN) were determined. Due to the noncarbonate parent rock material as well as the low pH values $\left(<4\right.$ in $\left.\mathrm{CaCl}_{2}\right)$ of the soils and sediments on the Ullafelsen $($ Geitner et al., 2011), the measured TC values can be considered as TOC values. From these data, the TOC/N ratio was calculated. Steroid ( $\Delta^{5}$-sterols, stanols, stanones) and bile acid analyses were performed according to Birk et al. (2012), Wiedner et al. (2015) and Lühe et al. (2020). Analyses took place at the Institute of Agronomy and Nutritional Sciences, Soil Biogeochemistry, Martin-Luther-University Halle-Wittenberg (Germany).

In brief, a total lipid extract (TLE) was obtained by soxhlet extraction for 36 hours using a solvent mixture of dichloromethane/methanol (2:1, v/v, $180 \mathrm{ml})$. The weight of sample depended on the TOC content of the sample and ranged for the 37 analyzed soil samples from 1.6 to $5.0 \mathrm{~g}$ of finely ground material. For faeces, it is necessary to use a much smaller weight due to the higher TOC contents. In case of our two faeces (cattle and sheep), the weight of sample taken was $\sim 60 \mathrm{mg}$. Prior to extraction, $100 \mu \mathrm{g}$ of $\alpha$-preganol and $100 \mu \mathrm{g}$ of isodeoxycholic acid were added to each sample as recovery standard (internal standard 1, IS1) for the neutral and acid lipid fractions, respectively.

180 After extraction, the solvent was removed and the TLEs were saponified using $3.5 \mathrm{ml}$ of $0.7 \mathrm{M} \mathrm{KOH}$ in methanol at room temperature overnight for approx. 12 hours. Neutral lipids ( $\Delta^{5}$-sterols, stanols, stanones) as well as acidic lipids (bile acids) were separated by sequential liquid-liquid extraction. To obtain the neutral lipid fraction, the extracts were spiked with $10 \mathrm{ml}$ $\mathrm{H}_{2} \mathrm{O}$ and afterwards separated from the aqueous phase with $3 \times 15 \mathrm{ml}$ chloroform. For gaining the acidic lipid fraction, the aqueous solution was acidified with $6 \mathrm{M} \mathrm{HCl}(\mathrm{pH} \leq 3-4)$ and the bile acids were extracted with $3 \times 15 \mathrm{ml}$ chloroform. Both fractions were separately collected in flasks and evaporated under nitrogen.

Before purification by solid phase extraction (SPE), bile acids were methylated by adding $1 \mathrm{ml}$ of $1.25 \mathrm{M} \mathrm{HCl}$ in methanol and heating at $80^{\circ} \mathrm{C}$ for 2 hours. Bile acids and fatty acid methyl esters were extracted with $1 \mathrm{ml} \mathrm{H}_{2} \mathrm{O}$ and $3 \times 1 \mathrm{ml} n$-hexane. SPE was performed using glass columns $(\varnothing 11 \mathrm{~mm}$ ) containing $1.5 \mathrm{~cm}$ activated silica gel (Mesh: 70-230; pore size: $100 \mathrm{~A}$; type: Merck 10187; Sigma-Aldrich) in $n$-hexane. After pre-conditioning with $5 \mathrm{ml}$ dichloromethane/n-hexane (2:1, v/v), the extracts were transferred with dichloromethane $/ n$-hexane $(2: 1, \mathrm{v} / \mathrm{v})$ on the silica-column. After elution of the fatty acid methyl esters with $5 \mathrm{ml}$ dichloromethane/n-hexane $(2: 1, \mathrm{v} / \mathrm{v})$, bile acid methyl esters were eluted with $5 \mathrm{ml}$ of dichloromethane/methanol (2:1, v/v) and collected in reactivials. The dried bile acid methyl esters were redisolved in $50 \mu 1$ toluene and silylated with $98 \mu$ BSTFA (N,O-Bis-(trimethylsilyl)-trifluoracetamid; puriss; Sigma-Aldrich) and $2 \mu 1$ TSIM (1(Trimethylsilyl)imidazol; puriss; Sigma-Aldrich) at $80^{\circ} \mathrm{C}$ for 1 hour. After cooling, $50 \mu \mathrm{l} 5 \alpha$-cholestan $\left(10 \mathrm{ng} \mu \mathrm{l}^{-1}\right.$ in toluene) were added as internal standard 2 (IS2). 
https://doi.org/10.5194/bg-2021-186

Preprint. Discussion started: 22 July 2021

(c) Author(s) 2021. CC BY 4.0 License.

(c) (i)

For the SPE of the neutral lipid fraction, activated silica gel (Mesh: 70-230; pore size: 100 A; type: Merck 10187; SigmaAldrich) was deactivated with $5 \% \mathrm{H}_{2} \mathrm{O}$. The neutral lipid extract was transferred with $n$-hexane to the SPE glass columns ( $\varnothing$ $11 \mathrm{~mm}$ ) containing $1.5 \mathrm{~cm}$ deactivated silica gel. Preconditioning was carried out with $5 \mathrm{ml} n$-hexane. By adding $5 \mathrm{ml} \mathrm{n}$ hexane, aromatic and aliphatic fractions were eluted, but not used for further analyses. The steroid-containing fraction was eluted with $3 \mathrm{ml}$ dichloromethane and $2 \mathrm{ml}$ dichloromethane/acetone $(2: 1, \mathrm{v} / \mathrm{v})$. The eluates were collected in reactivials before drying under nitrogen $\left(\mathrm{N}_{2}\right)$. Subsequently, steroids were silylated by adding $100 \mu$ l Sylon HTP (a mixture of HMDS+TMCS+Pyridine (3:1:9, v:v:v); puriss; Supelco) and derivatized at $70^{\circ} \mathrm{C}$ for 1 hour. The eluates were dried with $\mathrm{N}_{2}$ after cooling. $50 \mu \mathrm{l}$ of $5 \alpha$-cholestan (10 ng $\mu^{-1}$ in toluene) as internal standard 2 (IS2) and $100 \mu \mathrm{l}$ of toluene were added to the dried steroid eluates.

205 For GC-MS measurements, GC-vials with $100 \mu \mathrm{l}$ inserts were used for transferring the neutral lipids and the bile acids. External standards containing all analyzed steroids and bile acids in six different concentrations $(5,10,25,50,100,250 \mu l$ per vial) were derivatized simultaneously with the soil and faeces samples. The internal standard 1 was added in the same concentration for each external standard beforehand. $50 \mu \mathrm{l}$ of the internal standard 2 were added to each external standard mixture after their derivatization.

210 Quantification of all steroid and bile acid substances took place using gas chromatography-mass spectrometry (GC-MS) with a 5971 A quadrupole mass spectrometer connected to a HP5090 gas chromatograph (both made from Hewlett Packard) with a DB-5 MS $30 \mathrm{~m}$ fused silica column ( $25 \mathrm{~mm}$ ID and $0.25 \mu \mathrm{m}$ film thickness, Agilent Technologies).

All measurements of steroids and bile acids were conducted with the following settings for GC-MS: injection volume: $1 \mu$, carrier gas: helium (purity of 5), injector temperature: $290^{\circ} \mathrm{C}$, injection by splitless, interface temperature: isotherm at $280^{\circ} \mathrm{C}$.

215 The column temperature program of the gas chromatography was held at $80^{\circ} \mathrm{C}$ for $1.5 \mathrm{~min}$ and then raised at $12^{\circ} \mathrm{C} \min ^{-1}$ to $265^{\circ} \mathrm{C}$. Further steps are the increase of the temperature at $0.8^{\circ} \mathrm{C} \mathrm{min}^{-1}$ to $288^{\circ} \mathrm{C}$ and at $10^{\circ} \mathrm{C} \mathrm{min}^{-1}$ to $300^{\circ} \mathrm{C}$ afterwards, whereas it was kept for $12 \mathrm{~min}$.

\subsection{Data analysis}

For a detailed interpretation of the measured results in terms of degradation effects and distinguishing between omnivore-, herbivore- or plant-derived faecal biomarkers, the following ratios were calculated and plotted as box plot diagrams:
Ratio $1=$
Coprostanol+Epicoprostanol
(Eqn. 1)

Ratio $2=\frac{\text { Coprostanol }+ \text { Epicoprostanol }}{5 \beta-\text { Stigmastanol }+ \text { Epi-5 } \beta-\text { Stigmastanol }}$

(Eqn. 2) 
https://doi.org/10.5194/bg-2021-186

Preprint. Discussion started: 22 July 2021

(c) Author(s) 2021. CC BY 4.0 License.

(c) (i)

Ratio $4=\quad \frac{5 \beta-\text { Stigmastanol }}{\text { Epi-5 } \beta \text {-Stigmastanol }}$

(Eqn. 4)

230 According to Bull et al. (1999a) and Schroeter et al. (2020), we used ratio 1 to estimate microbial degradation of steroids and to identify human faeces input (Wiedner et al., 2015). It is known that soil microorganisms contribute to degradation of steroids in soils (Bull et al., 2001). 5 $\alpha$-cholestanol is a degradation product of cholesterol, transformed by soil microorganisms. This ratio considers the input and preservation of stanols. High values for ratio 1 (0.7-1) indicate an increased faeces deposition, while values < 0.7 indicate low faeces input (Schroeter et al., 2020; Bull et al., 1999a).

235 For distinguishing between human and herbivore faeces, ratio 2 can be applied. A dominant steroid marker in omnivore faeces such as humans or pigs is coprostanol, whereas $5 \beta$-stigmastanol is a typical steroid marker for herbivore faeces. To account for ongoing epimerization of $5 \beta$-stanols in soils, both epimers are included in this ratio. Major input of human faeces results in values $>1$, whereas values $<1$ indicate an input of herbivore faeces (Ossendorf et al., 2019).

Ratio 3 was calculated for differentiation between plant-derived steroids and herbivore faeces. According to Prost et al. (2017),

$240 \beta$-sitosterol belongs to the typical $\Delta^{5}$-sterols, which are characteristic for plant biomass and thus normally occur at high abundance in soils. Values between 0 and 0.5 suggest low input of $\beta$-sitosterol and values between 0.5 and 1 point at a high occurrence of this plant sterol. It has to be considered that faeces of ruminants can also contain high amounts of $\beta$-sitosterol due to their plant-dominated diet (Schroeter et al., 2020; Haurrault et al., 2019).

Ratio 4 was calculated for all soil samples and can be used as proxy for degradation of $5 \beta$-stigmastanol. Epi- $5 \beta$-stigmastanol 245 is a transformation product (epimer) of $5 \beta$-stigmastanol and is often found in anaerobic environments and soils (Lühe et al., 2018). This transformation is induced by soil composting (Prost et al., 2017). With increasing degradation, ratio 4 gets lower due to the higher proportion of the steroid epi-5 $\beta$-stigmastanol.

The following equation was applied for calculating a bile acid ratio:

Ratio $5=\quad \frac{\text { Deoxycholic acid }(D C A)}{\text { Lithocholic acid }(L C A)} \quad$ (Eqn. 5)

Based on the bile acids deoxycholic acid and lithocholic acid, ratio 5 can be used for distinguishing ruminant from human faeces. Prost et al. (2017) published reference values, which are characteristic for ruminant species and humans respectively. 255 Human faeces contain not only high amounts of coprostanol, but also of lithocholic acid. In contrast, ruminant faeces show a dominance of deoxycholic acid (Shillito et al., 2020). A small ratio 5 (3-5) indicates a dominance of human faeces, whereas high values (5-21) show a dominance of ruminant faeces such as cattle or sheep (Prost et al., 2017). 
https://doi.org/10.5194/bg-2021-186

Preprint. Discussion started: 22 July 2021

(c) Author(s) 2021. CC BY 4.0 License.

(c) (i)

\section{Results and Discussion}

\subsection{Biomarker patterns of faeces from predominating animals}

260 The total steroid contents (TSC) of modern cattle and sheep faeces range from 2401.6 to $2671.6 \mu \mathrm{g} / \mathrm{g}$ and 2109.8 to 2421.9 $\mu \mathrm{g} / \mathrm{g}$, respectively (Table S3). The total bile acid contents (TBAC) of modern cattle and sheep faeces range from 55.9 to 86.8 $\mu \mathrm{g} / \mathrm{g}$ and 78.6 to $216.9 \mu \mathrm{g} / \mathrm{g}$, respectively (Table S4).

For checking the robustness of our results, we repeated the analyses of our faeces samples twice (Table S3; Table S4). Figure 4 illustrates the steroid and bile acid contents and their patterns in modern cattle and sheep faeces. The following results refer to measurement 1 (Table S3; Table S4).

The predominating steroid in cattle faeces is $5 \beta$-stigmastanol $(930.9 \mu \mathrm{g} / \mathrm{g})$, whereas epi-5 3 -stigmastanol $(666.5 \mu \mathrm{g} / \mathrm{g})$ shows a predominance in sheep faeces (Fig. 4). For comparison, Prost et al. (2017) did not find epi-5 $\beta$-stigmastanol to predominate in sheep faeces. It cannot be excluded, that the predominance of epi-5 $\beta$-stigmastanol in our sample is induced by strong epimerization.

270 The coprostanol content in modern cattle faces is $125.7 \mu \mathrm{g} / \mathrm{g}$, whereas the coprostanol content of $173.4 \mu \mathrm{g} / \mathrm{g}$ was detected in modern sheep faeces. The plant-derived steroid $\beta$-sitosterol shows $347.9 \mu \mathrm{g} / \mathrm{g}$ in modern cattle faeces and $255.9 \mu \mathrm{g} / \mathrm{g}$ in modern sheep faeces (Fig. 4).

Bull et al. (1999a) and Prost et al. (2017) introduced ratio 1 for the identification of faeces origin. Typical ratio 1 is $\sim 0.8$ for cattle and sheep, whereas $\sim 1$ is typical for human faeces. Our results revealed a ratio 1 of 0.8 for both modern faeces samples.

275 For the identification of ruminant faeces input, we calculated ratio 2 . Cattle and sheep faeces yielded ratio 2 of $\sim 0.1$ and $\sim 0.2$, respectively. These results are in agreement with data of Prost et al. (2017). Ratios $>1$ indicate human or other omnivore faeces input. Our faeces samples yielded ratio 3 of $\sim 0.2$ for cattle and sheep. This ratio reflects the predominance of $5 \beta$ stigmastanol and epi-5 $\beta$-stigmastanol over $\beta$-sitosterol.

The most dominant bile acid in our modern ruminant faeces is deoxycholic acid (38.7 $\mu \mathrm{g} / \mathrm{g}$ and $55.0 \mu \mathrm{g} / \mathrm{g}$ in cattle and sheep faeces, respectively), being in agreement with literature data of Kuhajda et al. (2006) and Prost et al. (2017). Lithocholic acid as marker for the input of human faeces was found in modern animal faeces only at low amounts $(4.2 \mu \mathrm{g} / \mathrm{g}$ and $2.9 \mu \mathrm{g} / \mathrm{g}$ in cattle and sheep faeces, respectively (Fig. 4)).

According to Prost et al. (2017), ratio 5 ranged from 5-21 and 8-12 for cattle and sheep faeces, respectively. Based on our results, ratio 5 showed a ratio of 9.2 for cattle faeces and 18.8 for sheep faeces. For comparison, ratio 5 is typical for human

285 faeces when in a range from 3 to 4.5 . Accordingly, ratio 5 is highly promising for distinguishing between ruminant versus human faeces in soils. Unfortunately, steroid and bile acid patterns of our analyzed ruminant faeces allow no differentiation between cattle and sheep.

All three measurements yielded similar content for sterols, stanols and stanones. By contrast, measurement 1 showed higher contents of the bile acid deoxycholic acid but lower contents of oxolithocholic acid for both modern faeces samples (Table 
https://doi.org/10.5194/bg-2021-186

Preprint. Discussion started: 22 July 2021

(c) Author(s) 2021. CC BY 4.0 License.

(c) (i)

290 S4). The latter can be synthesized by oxidation of the hydroxyl groups of deoxycholic acid (Kuhajda et al., 2006; Marion et al., 2019; Sakai et al., 1980).

\section{- Figure 4 -}

\section{3.2 Faecal biomarker contents and patterns in soils}

The total steroid content of the 37 soil samples from the Ullafelsen ranged from 1.2 to $198.1 \mu \mathrm{g} / \mathrm{g}$ (Fig. 5). The OAh1 and OAh3 horizons yielded maxima coinciding with TOC maxima. The lowest steroid content was measured in the Bh, Bs and $\mathrm{BvCv}$ horizons, whereas the steroid content of the $\mathrm{E}$ (LL) horizon was intermediate (2.3 to $58.6 \mu \mathrm{g} / \mathrm{g}$ (Fig.5)).

The total bile acid content of the 37 soil samples from the Ullafelsen ranged from 0 to $6.8 \mu \mathrm{g} / \mathrm{g}$ and show their maximum in 300 the topsoil horizons OAh1 and OAh2 (Fig. 5). In comparison to the maximum steroid content in the OAh1 horizon, the maximum bile acid content of $6.8 \mu \mathrm{g} / \mathrm{g}$ was detected in the OAh2 horizon. Similar to the steroid contents, the bile acid contents are much higher in the topsoil horizons OAh1, OAh2, and OAh3 (0.5 to $6.8 \mu \mathrm{g} / \mathrm{g}$ ) and lower in the subsoil horizons E (LL), $\mathrm{Bh}, \mathrm{Bs}$ and $\mathrm{BvCv}(0$ to $0.9 \mu \mathrm{g} / \mathrm{g}$ ) (Fig. 5). Steroids and bile acids in the subsoils can be induced by bioturbation and/or roots of plants (Piironen et al., 2000). The most detected steroid in the subsoils is $\beta$-sitosterol. Thomas and Hale (1983) as well as

305 Verma and Gupta (2013) found that roots or root exudates contain also plant steroids such as $\beta$-sitosterol. Hence, the small contents of steroids in the subsoil horizons at the Ullafelsen are mainly caused by the influence of $\beta$-sitosterol due to the strong rooting in the soil matrix. There is no deformation of soil horizons, thus we exclude the influence of bioturbation.

\section{- Figure 5 -}

The most abundant steroid in all soil samples is $\beta$-sitosterol with a maximum content of $150.1 \mu \mathrm{g} / \mathrm{g}$ measured in an OAh3 horizon (Fig. 6; Table S1). $\beta$-sitosterol is the typical $\Delta^{5}$-steroid for plant biomass and reflects the predominating vegetation signal (Prost et al., 2017; Holtvoeth et al., 2010). Due to the plant diet, $\beta$-sitosterol is eaten by ruminants and can be detected in their faeces (Haurrault et al., 2019). Cholesterol as the dominating $\Delta^{5}$-steroid in animal tissues has a maximum content of $3156.2 \mu \mathrm{g} / \mathrm{g}$ detected in an OAh1 horizon (Fig.6; Table S1).

Due to microbial degradation in soils, $5 \alpha$-stigmastanol and $5 \alpha$-cholestanol (both belonging to the $5 \alpha$-stanols), are partly produced from their steroid precursors $\beta$-sitosterol and cholesterol (Björkhem and Gustafsson, 1971). These $5 \alpha$-stanols also occur in small amounts in fresh plant material and animal tissue (Bull et al., 2002; Noda et al., 1988). The maximum content of $5 \alpha$-stigmastanol is $32.1 \mu \mathrm{g} / \mathrm{g}$ in an OAh3 horizon, whereas $1.4 \mu \mathrm{g} / \mathrm{g}$ is the maximum content of $5 \alpha$-cholestanol detected in an OAh1 horizon (Fig. 6; Table S1).

The steroid coprostanol as marker for human faeces was detected at highest content of $0.2 \mu \mathrm{g} / \mathrm{g}$ in an OAh1 and OAh2 horizon. Epi-coprostanol as transformation product of coprostanol due to microbial degradation (Bull et al., 1999a; Lauer et al., 2014) 
https://doi.org/10.5194/bg-2021-186

Preprint. Discussion started: 22 July 2021

(c) Author(s) 2021. CC BY 4.0 License.

(c) (i)

was not detectable in our soils (Fig. 6; Table S1). $5 \beta$-stigmastanol and epi-5 $\beta$-stigmastanol (epimerization product of $5 \beta$ stigmastanol) as marker for ruminant faeces have their maximum content of $3.3 \mu \mathrm{g} / \mathrm{g}$ and $3.2 \mu \mathrm{g} / \mathrm{g}$ in an OAh1 horizon, respectively (Fig.6; Table S1).

The most abundant bile acid in the analysed soil samples was deoxycholic acid with a maximum content of $4.2 \mu \mathrm{g} / \mathrm{g}$ in an OAh1 and OAh2 horizon (Fig. 6; Table S1). It predominates in ruminants such as cattle and sheep (Prost et al., 2017; Kuhajda et al., 2006). Lithocholic acid as the dominating bile acid in human faeces (Shillito et al., 2020) showed a maximum content of $0.5 \mu \mathrm{g} / \mathrm{g}$ in an OAh2 horizon (Fig.6; Table S1). Wiedner et al. (2015) reported similar deoxycholic acid and lithocholic acid contents for anthropogenic dark earths in northern Germany.

Oxolithocholic acid was also detected in our soil samples and has a maximum content of $1.7 \mu \mathrm{g} / \mathrm{g}$ in an OAh1 horizon (Fig. 6; Table S1). As discussed in 3.1, ruminant faeces also containing oxolithocholic acid at low abundance. However, according to Marion et al. (2019) we cannot exclude that oxolithocholic acid is formed by microorganisms in soils, such as Clostridium scindens, due to transformation of deoxycholic acid to oxolithocholic acid.

- Figure 6 -

Overall, our results indicate that a strong input of faeces from cattle and sheep into the soils on the Ullafelsen occurred. By contrast, low lithocholic acid and coprostanol contribution point to a minor influence of human faeces at the Ullafelsen. This first interpretation should be confirmed by the applied faecal ratios of the considered steroids and bile acids.

\subsection{Identification of faeces origin based on specific steroid and bile acid ratios}

Ratio 1 ranged from 0 to 0.3 (Fig. 7). Human faeces normally exhibit ratio $1>0.7$ (Bull et al., 1999a; Prost et al., 2017). Therefore, our results corroborate a low input of human faeces into soils at the Ullafelsen.

Ratio 2 ranged from 0 to 0.4 (Fig. 7) and showed a maximum in the Bh horizon due to the higher content of epi-5 $\beta$-stigmastanol compared with the content of $5 \beta$-stigmastanol (Table S1). Our results confirm a predominance of $5 \beta$-stigmastanol and epi- $5 \beta$ stigmastanol, which indicate a strong input of ruminant faeces into soils at the Ullafelsen.

Ratio 3 ranged from 0.95 to 1 (Fig. 7), demonstrating a strong influence of plant-derived steroids in soils at the Ullafelsen caused by the high contribution of $\beta$-sitosterol (Fig.6). High ratio 3 in the $\mathrm{Bh}$, Bs and $\mathrm{BvCv}$ horizons can be explained by decreasing $5 \beta$-stigmastanol and epi-5 $\beta$-stigmastanol contents. Roots of plants contribute to an input of $\beta$-sitosterol into subsoils (Piironen et al., 2000).

Ratio 5 ranged from 4.1 to 23.5 (Fig. 7), decreasing from top to bottom. A ratio < 5 indicates a dominance of human faeces, whereas a ratio $>5$ corroborates a dominance of ruminant faeces (Prost et al., 2017). No lithocholic acid was detected in the $\mathrm{Bs}$ and $\mathrm{BvCv}$ horizons. Apart from the outlier of 4.1, our results showed a clear dominance of ruminant faeces input into soils at the Ullafelsen due to the high content of deoxycholic acid. The outlier of 4.1, detected in an E (LL) horizon, can be allocated to a close-by-trench soil profile (1.9 NE E 1 (LL)), which is beyond the archaeological excavation area on the Ullafelsen. For 
https://doi.org/10.5194/bg-2021-186

Preprint. Discussion started: 22 July 2021

(c) Author(s) 2021. CC BY 4.0 License.

(c) (i)

this E (LL) horizon, we cannot exclude the input of human faeces regarding ratio 5, being based on the content of deoxycholic acid $(0.3 \mu \mathrm{g} / \mathrm{g})$ and lithocholic acid $(0.1 \mu \mathrm{g} / \mathrm{g})($ Table $\mathrm{S} 2)$.

- Figure 7 -

360

Ratio 4 ranged from 0 to 1.0 (Fig. 8), decreasing from the topsoils to the subsoils. As discussed in section 3.1, we observed a degradation effect of $5 \beta$-stigmastanol in our soils. Our results corroborate a higher degradation in the E (LL), Bh, Bs and BvCv

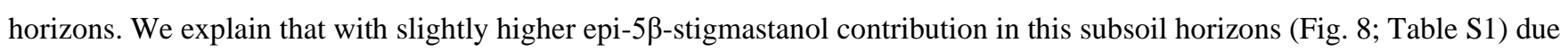
to epimerization (Bull et al., 1999a; Bull et al., 1999b; Bull et al., 2003; Prost et al., 2017). For a robust identification of faeces origin, we recommend to consider the degradation effect and to include epi-5 $\beta$-stanols in steroid ratios (Bull et al., 2001).

- Figure 8 -

\section{Conclusions and outlook}

This study presents the first results of faecal biomarker analyses carried out on the prehistorical encampment site of Ullafelsen,

370 Fotsch Valley, Austria. Steroid and bile acid patterns of contemporary ruminants showed a dominance of $5 \beta$-stigmastanol, whereas epi-5 $\beta$-stigmastanol as degradation product of $5 \beta$-stigmastanol has to be considered for sheep. Deoxycholic acid was detected as the dominant bile acid for cattle and sheep. These data together with data of Prost et al. (2017) were used for the interpretation of the faecal biomarker results from the geoarchaeological soil samples.

The highest steroid and bile acid amounts were found in the OAh3 and OAh2 horizons, respectively. The dominant steroid in 375 our soils is $\beta$-sitosterol as plant-derived $\Delta^{5}$-steroid. Deoxycholic acid as the dominant bile acid and faecal marker for ruminants occurred in high contents in all topsoils corroborate actual grazing by cattle and sheep. Human faeces could be detected only to a minor extent. Calculated ratios (R1-R5) confirmed the negligible input of human faeces and the dominant input of ruminant faeces (cattle and sheep) at the Ullafelsen. Modern vegetation and ruminant faeces, associated with the plant-based diet of cattle and sheep, could have induced the high input plant-derived steroids in our soils.

380 Data of all soil samples from soil profiles on the Ullafelsen represent the modern signal of ruminant faeces and of plant-derived steroids regarding to the meaningful faecal biomarker contents in the topsoils. Based on our faecal biomarker results, we cannot confirm the Mesolithic settlement of hunter-gatherers at the Ullafelsen. According to Schäfer et al. (2016), the archaeological site of Ullafelsen was used for fireplaces and social living in the Mesolithic period. However, it cannot be excluded that human faeces markers will be detected in higher content close-by the archaeological excavation area in future investigations. We assume that sites close-by the archaeological excavation area were used as "toilet". 
https://doi.org/10.5194/bg-2021-186

Preprint. Discussion started: 22 July 2021

(c) Author(s) 2021. CC BY 4.0 License.

(c) (i)

Discussions

A robust age control for faecal biomarkers on the Ullafelsen is challenging because of lacking age chronology. This study allows thus no reconstruction for the onset of alpine pastoralism. We assume the input of faecal steroids and bile acids in the Holocene since the beginning of the alpine pastoralism in the Neolithic and Bronze Age (Knierzinger et al., 2020).

In order to chronologically identify the history of land use in the Fotsch Valley, we suggest to investigate faecal biomarkers on mire archives in the Fotsch Valley. Previous studies of two subalpine mire archives in the near surroundings of the prehistorical encampment site of Ullafelsen demonstrate the high potential for palaeoenvironmental reconstructions.

\section{Supplementary Material}

Table S1: Overview over all faecal biomarker soil samples from the prehistorical encampment site of Ullafelsen in the Fotsch Valley, Stubai Alps (Austria). Steroid contents (in $\mu \mathrm{g} / \mathrm{g}$ dry matter) for sterols, stanols and stanones as well as ratios are presented.

Table S2: Overview over all faecal biomarker soil samples from the prehistorical encampment site of Ullafelsen in the Fotsch Valley, Stubai Alps (Austria). Bile acid contents (in $\mu \mathrm{g} / \mathrm{g}$ dry matter) as well as ratios are presented.

Table S3: Sterol, stanol and stanone contents (in $\mu \mathrm{g} / \mathrm{g}$ dry matter) for 3 replication measurements of modern cattle and sheep faeces from the prehistorical encampment site of Ullafelsen in the Fotsch Valley, Stubai Alps (Austria).

Table S4: Bile acid contents (in $\mu \mathrm{g} / \mathrm{g}$ dry matter) for 3 replication measurements of modern cattle and sheep faeces from the prehistorical encampment site of Ullafelsen in the Fotsch Valley, Stubai Alps (Austria).

\section{Authors contributions}

The project idea was developed by MZ in cooperation with BG, DS and CG. Fieldwork was done by ML, MZ, JNH, DS and CG. ML performed most of the laboratory work with contributions made by TB, BG and MZ. The manuscript was prepared by ML. All co-authors contributed to the discussion of the results and read an approved the manuscript.

\section{Competing interests}

The authors declare that they have no conflict of interest.

\section{Acknowledgements}

We greatly acknowledge Prof. Dr. Sixten Bussemer for support of fieldwork and helpful discussions on pedogenesis of the 410 archaeological soil profiles from the Ullafelsen. Special thanks go to Oliver Kiewert and his team from the Bergheim hostel for excellent food and accommodation during the period of fieldwork. We also thank Heike Maennicke and Marianne Zech (form. Benesch) for supporting laboratory work and for the pleasant collaboration at any time. Last but not least, we thank the 
https://doi.org/10.5194/bg-2021-186

Preprint. Discussion started: 22 July 2021

(c) Author(s) 2021. CC BY 4.0 License.

(c) (i)

reviewers and handling editor. The German Research Foundation (GL 327/23-1 and ZE 844/12-1) kindly provided project funding.

\section{References}

Baeten, J., Marinova, E., Laet, V. de, Degryse, P., Vos, D. de and Waelkens, M.: Faecal biomarker and archaeobotanical analyses of sediments from a public latrine shed new light on ruralisation in Sagalassos, Turkey, Journal of Archaeological Science, 39, 1143-1159, https://doi.org/10.1016/j.jas.2011.12.019, 2012.

Birk, J. J., Dippold, M., Wiesenberg, G. L. B. and Glaser, B.: Combined quantification of faecal sterols, stanols, stanones and bile acids in soils and terrestrial sediments by gas chromatography-mass spectrometry, Journal of Chromatography A, 1242, 1-10, https://doi.org/10.1016/j.chroma.2012.04.027, 2012.

Birk, J. J., Teixeira, W. G., Neves, E. G. and Glaser, B.: Faeces deposition on Amazonian Anthrosols as assessed from 5 $\beta$ stanols, Journal of Archaeological Science, 38, 1209-1220, https://doi.org/10.1016/j.jas.2010.12.015, 2011.

Björkhem, I. and Gustafsson, J.: Microbial transformation of cholesterol into coprostanol, European Journal of Biochemistry, 21, 428-432, https://doi.org/10.1111/j.1432-1033.1973.tb02968.x, 1971.

Bull, I. D., Betancourt, P. P. and Evershed, R. P.: An Organic Geochemical Investigation of the Practice of Manuring at a Minoan site on Pseira Island, Crete, Geoarchaeology, 16 (2), 223-242, https://doi.org/10.1002/15206548(200102)16:2<223::AID-GEA1002>3.0.CO;2-7, 2001.

Bull, I. D., Elhmmali, M. M., Perret, V., Matthews, W., Roberts, D. J. and Evershed, R. P.: Biomarker evidence of faecal deposition in archaeological sediments at Çatalhöyük, in: Changing materialities at Çatalhöyük: reports from the 19951999 seasons, edited by: Hodder, I., Cambridge, Great Britain, 415-420, 2005.

Bull, I. D., Elhmmali, M. M., Roberts, D. J. and Evershed, R. P.: The application of steroidal biomarkers to track the abandonment of a Roman wastewater course at the Agora (Athens, Greece), Archaeometry, 45, 149-161, https://doi.org/10.1111/1475-4754.00101, 2003.

Bull, I. D., Lockheart, M. J., Elhmmali, M. M., Roberts, D. J. and Evershed, R. P.: The origin of faeces by means of biomarker detection, Environmental International, 27 (8), 647-654, https://doi.org/10.1016/S0160-4120(01)00124-6, 2002.

Bull, I. D., Simpson, I. A., Bergen van, P. F. and Evershed, R. P.: Muck 'n' molecules: organic geochemical methods for detecting ancient manuring, Antiquity, 73, 86-96, https://doi.org/10.1017/S0003598X0008786X, 1999a. 
https://doi.org/10.5194/bg-2021-186

Preprint. Discussion started: 22 July 2021

(c) Author(s) 2021. CC BY 4.0 License.

Bull, I. D., Simpson, I. A., Dockrill, S. J. and Evershed, R. P.: Organic geochemical evidence for the origin of ancient anthropogenic soil deposits at Tofts Ness, Sanday, Orkney, Organic Geochemistry, 30, 535-556, https://doi.org/10.1016/S0146-6380(99)00020-0, 1999b.

Cornelissen, M. and Reitmaier, T.: Filling the gap: Recent Mesolithic discoveries in the central and south-eastern Swiss Alps, Quaternary International, 423 (22), 9-22, https://doi.org/10.1016/j.quaint.2015.10.121, 2016.

Egli, M., Mirabella, A. and Sartori, G.: The role of climate and vegetation in weathering and clay mineral formation in late Quaternary soils of the Swiss and Italian Alps, Geomorphology, 102, 307-324, https://doi.org/10.1016/j.geomorph.2008.04.001, 2008.

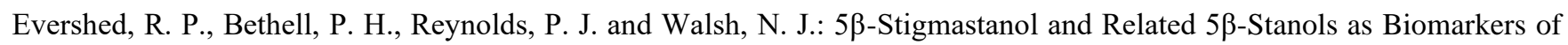
Manuring: Analysis of Modern Experimental Material and Assessment of the Archaeological Potential, Journal of Archaeological Science, 24, 485-495, https://doi.org/10.1006/jasc.1996.0132, 1997.

Fontana, F., Visentin, D. and Wierer, U.: MesoLife. A Mesolithic perspective on Alpine and neighbouring territories, Quaternary International, 423 (22), 1-4, https://doi.org/10.1016/j.quaint.2016.06.016, 2016.

Geitner, C., Bussemer, S., Ehrmann, O., Ikinger, A., Schäfer, D., Traidl, R. and Tscherko, D.: Bodenkundlich-stratigraphische Befunde am Ullafelsen im hinteren Fotschertal sowie ihre landschaftsgeschichtliche Interpretation, in: Das Mesolithikum-Projekt Ullafelsen (Teil 1). Mensch und Umwelt im Holozän Tirols 1, edited by: Schäfer, D., Philipp von Zabern, Darmstadt, Germany, 109-151, 2011.

Geitner, C. and Schäfer, D.: Interdisziplinäre Zusammenarbeit an der Schnittstelle von Archäologie und Bodenkunde im Gebirge - Grundsätzliche Überlegungen und Beispiele des Mesolithfundplatzes Ullafelsen (Tirol), in: Archäologie in den Alpen: Alltag und Kult, edited by: Mandl, F. and Stadler, H., ANISA, Verein für alpine Forschung, Haus im Ennstal, 25-42, 2010.

Geitner, C., Schäfer, D., Bertola, S., Bussemer, S., Heinrich, K. and Waroszewski, J.: Landscape archaeological results and discussion of Mesolithic research in the Fotsch valley (Tyrol), in: From the foreland to the Central Alps - Field trips to selected sites of Quaternary research in the Tyrolean and Bavarian Alps (DEUQUA EXCURSIONS), edited by: Kerschner, H., Krainer, K. and Spötl, C., Geozon Science Media, Berlin, Germany, 106-115, 2014.

465 Gilck, F. and Poschlod, P.: The origin of alpine farming: A review of archaeological, linguistic and archaeobotanical studies in the Alps, The Holocene, 29 (9), 1503-1511, https://doi.org/10.1177/0959683619854511, 2019.

Glaser, B. and Birk, J. J.: State of the scientific knowledge on properties and genesis of Anthropogenic Dark Earths in Central Amazonia (terra preta de Indio), Geochimica et Cosmochimica Acta, 82, 39-51, https://doi.org/10.1016/j.gca.2010.11.029, 2012. 
https://doi.org/10.5194/bg-2021-186

Preprint. Discussion started: 22 July 2021

(c) Author(s) 2021. CC BY 4.0 License.

Glaser, B., Haumaier, L., Guggenberger, G. and Zech, W.: The "terra preta" phenomenon: a model for sustainable agriculture in the humid tropics, Naturwissenschaften, 88 (1), 37-41, https://doi.org/10.1007/s001140000193, 2001.

Hartmann, M.-A.: Plant sterols and the membrane environment, Trends in Plant Science, 3 (5), 170-175, https://doi.org/10.1016/S1360-1385(98)01233-3, 1998.

Haurrault, L., Milek, K., Jarde, E., Jeanneau, L., Derrien, M. and Anderson, D. G.: Faecal biomarkers can distinguish specific mammalian species in modern and past environments, PLoS ONE, 14 (2), 1-26, https://doi.org/10.1371/journal.pone.0211119, 2019.

Holtvoeth, J., Vogel, H., Wagner, B. and Wolff, G. A.: Lipid biomarkers in Holocene and glacial sediments from ancient Lake Ohrid (Macedonia, Albania), Biogeosciences, 7, 3473-3489, https://doi.org/10.5194/bg-7-3473-2010, 2010.

IUSS Working Group WRB.: World Reference Base for Soil Resources 2014, update 2015. International soil classification system for naming soils and creating legends for soil maps., 106, World Soil Resources Reports FAO, Rome, 2015.

Kemmer, I.: Die rezente Vegetation im inneren Fotschertal / Nördliche Stubaier Alpen, in: Das Mesolithikum-Projekt Ullafelsen (Teil 1). Mensch und Umwelt im Holozän Tirols 1, edited by: Schäfer, D., Philipp von Zabern, Darmstadt, Germany, 155-193, 2011.

Knierzinger, W., Drescher-Schneider, R., Knorr, K.-H., Drollinger, S., Limbeck, A., Brunnbauer, L., Horak, F., Festi, D. and Wagreich, M.: Anthropogenic and climate signals in late-Holocene peat layers of an ombrotrophic bog in the Styrian Enns valley (Austrian Alps), E\&G Quaternary Science Journal, 69, 121-137, https://doi.org/10.5194/egqsj-69-121-2020, 2020.

Kuhajda, K., Kandrac, J., Kevresan, S., Mikov, M. and Fawcett, J. P.: Structure and origin of bile acids: An overview, European Journal of Drug Metabolism and Pharmacokinetics, 31 (3), 135-143, https://doi.org/10.1007/BF03190710, 2006.

Lauer, F., Prost, K., Gerlach, R., Pätzold, S., Wolf, M., Urmersbach, S., Lehndorff, E., Eckmeier, E. and Amelung, W.: Organic Fertilization and Sufficient Nutrient Status in Prehistoric Agriculture? - Indications from Multi-Proxy Analyses of Archaeological Topsoil Relicts, PLoS ONE, 9 (9), https://doi.org/10.1371/journal.pone.0106244, 2014.

Lühe, B. von der, Birk, J. J., Dawson, L., Mayes, R. W. and Fiedler, S.: Steroid fingerprints: efficient biomarkers of human decomposition fluids in soil, Organic Geochemistry, 124, 228-237, https://doi.org/10.1016/j.orggeochem.2018.07.016, 2018.

Lühe, B. von der, Dawson, L., Mayes, R. W., Forbes, S. L. and Fiedler, S.: Investigation of sterols as potential biomarkers for the detection of pig (S. s. domesticus) decomposition fluid in soils, Forensic Science International, 230, 68-73, https://doi.org/10.1016/j.forsciint.2013.03.030, 2013. 
https://doi.org/10.5194/bg-2021-186

Preprint. Discussion started: 22 July 2021

(c) Author(s) 2021. CC BY 4.0 License.

Lühe, B. von der, Prost, K., Birk, J. J. and Fiedler, S.: Steroids aid in human decomposition fluid identification in soils of temporary mass graves from World War II, Journal of Archaeological Science: Reports, 32, 102431, https://doi.org/10.1016/j.jasrep.2020.102431, 2020.

Marion, S., Studer, N., Desharnais, L., Menin, L., Escrip, S., Meibom, A., Hapfelmeier, S. and Bernier-Latmani, R.: In vitro and in vivo characterization of Clostridium scindens bile acid transformations, Gut Microbes, 10 (4), 481-503, https://doi.org/10.1080/19490976.2018.1549420, 2019.

Nittel, P.: Geologie, Hydrogeologie und Geomorphologie des Fotschertales - Kartierungsergebnisse Projekt "Sellrain", in: Das Mesolithikum-Projekt Ullafelsen (Teil 1). Mensch und Umwelt im Holozän Tirols 1, edited by: Schäfer, D., Philipp von Zabern, Darmstadt, Germany, 61-92, 2011.

Noda, M., Tanaka, M., Seto, Y., Aiba, T. and Oku, C.: Occurrence of cholesterol as a major sterol component in leaf surface lipids, Lipids, 23, 439-444, https://doi.org/10.1007/BF02535517, 1988.

Ossendorf, G., Groos, A. R., Bromm, T., Tekelemariam, M. G., Glaser, B., Lesur, J., Schmidt, J., Akcar, N., Bekele, T., Beldados, A., Demissew, S., Kahsay, T. H., Nash, B. P., Nauss, T., Negash, A., Nemomissa, S., Veit, H., Vogelsang, R., Woldu, Z., Zech, W., Opgenoorth, L. and Miehe, G.: Middle Stone Age foragers resided in high elevations of the glaciated Bale Mountains, Ethiopia, Science, 365, 583-587, https://doi.org/10.1126/science.aaw8942, 2019.

Piironen, V., Lindsay, D. G., Miettinen, T. A., Toiva, J. and Lampi, A.: Plant sterols: biosynthesis, biological function and their importance to human nutrition, Journal of the Scientific of Food and Agriculture, 80, 939-966, https://doi.org/10.1002/(SICI)1097-0010(20000515)80:7<939::AID-JSFA644>3.0.CO;2-C, 2000.

Prost, K., Birk, J. J., Lehndorff, E., Gerlach, R. and Amelung, W.: Steroid Biomarkers Revisited - Improved Source Identification of Faecal Remains in Archaeological Soil Material, PLoS ONE, 12 (1), 1-30, https://doi.org/10.1371/journal.pone.0164882, 2017.

Reitmaier, T., Doppler, T., Pike, A. W. G., Deschler-Erb, S., Hajdas, I., Walser, C. and Gerling, C.: Alpine cattle management during the Bronze Age at Ramosch-Mottata, Switzerland, Quaternary International, 484, 19-31, https://doi.org/10.1016/j.quaint.2017.02.007, 2018.

Sakai, K., Makino, T., Kawai, Y. and Mutai, M.: Intestinal Microflora and Bile Acids - Effect of Bile Acids on the Distribution of Microflora and Bile Acid in the Digestive Tract of the Rat, Microbiology and Immunology, 24 (3), 187-196, https://doi.org/10.1111/j.1348-0421.1980.tb00578.x, 1980.

Schäfer, D.: Das Mesolithikum-Projekt Ullafelsen - Landschaftlicher Rahmen und archäologische Befunde. Arbeitsstand 2009/2010, in: Das Mesolithikum-Projekt Ullafelsen (Teil 1). Mensch und Umwelt im Holozän Tirols 1, edited by: Schäfer, D., Philipp von Zabern, Darmstadt, Germany, 245-351, 2011a. 
https://doi.org/10.5194/bg-2021-186

Preprint. Discussion started: 22 July 2021

(c) Author(s) 2021. CC BY 4.0 License.

\section{(c) (1)}

Schäfer, D.: Das Mesolithikum-Projekt Ullafelsen (Teil 1). Mensch und Umwelt im Holozän Tirols 1, Philipp von Zabern, Darmstadt, Germany, 2011b.

Schäfer, D., Bertola, S., Pawlik, A., Geitner, C., Waroszewski, J. and Bussemer, S.: The landscape-archaeological Ullafelsen Project (Tyrol, Austria), Preistoria Alpina, 48, 29-38, 2016.

Schlosser, E.: Das Fotschertal - regionale Klimatologie und gebirgsmeteorologische Aspekte, in: Das Mesolithikum-Projekt Ullafelsen (Teil 1). Mensch und Umwelt im Holozän Tirols 1, edited by: Schäfer, D., Philipp von Zabern, Darmstadt, Germany, 11-16, 2011.

Schroeter, N., Lauterbach, S., Stebich, M., Kalanke, J., Mingram, J., Yildiz, C., Schouten, S. and Gleixner, G.: Biomolecular Evidence of Early Human Occupation of a High-Altitude Site in Western Central Asia During the Holocene, Frontiers in Earth Science, 8, 1-20, https://doi.org/10.3389/feart.2020.00020, 2020.

Shillito, L.-M., Whelton, H. L., Blong, J. C., Jenkins, D. L., Connolly, T. J. and Bull, I. D.: Pre-Clovis occupation of the Americas identified by human fecal biomarkers in coprolites from Paisley Caves, Oregon, Science Advances, 6, 1-8, https://doi.org/10.1126/sciadv.aba6404, 2020.

Thomas, L. K. and Hale, M. G.: Effects of kinetin in the rooting medium on root exudation of free fatty acids and sterols from roots of Arachis hypogaea L. 'argentine' under axenic conditions, Soil Biology and Biochemistry, 15, 125-126, https://doi.org/10.1016/0038-0717(83)90131-1, 1983.

545 Verma, S. and Gupta, R.: Comparative estimation of $\beta$-sitosterol in roots, leaves and flowers of Clerodendrum infortunatum L., International Journal of Green Pharmacy, 7, 131-135, https://doi.org/10.4103/0973-8258.116394, 2013.

Wiedner, K., Schneeweiß, J., Dippold, M. and Glaser, B.: Anthropogenic Dark Earth in Northern Germany — The Nordic Analogue to terra preta de Índio in Amazonia, Catena, 132, 114-125, https://doi.org/10.1016/j.catena.2014.10.024, 2015.

Zech, M., Lerch, M., Bliedtner, M., Bromm, B., Seemann, F., Szidat, S., Salazar, G., Zech, R., Glaser, B., Haas, J. N., Schäfer, D. and Geitner, C.: Revisiting the subalpine Mesolithic site Ullafelsen in the Fotsch Valley, Stubai Alps, Austria - new insights into pedogenesis and landscape evolution from leaf wax-derived n-alkane biomarkers, black carbon and radiocarbon dating, E\&G Quaternary Science Journal, 70, 171-186, https://doi.org/10.5194/egqsj-70-171-2021, 2021.

Zech, W., Schad, P. and Hintermaier-Erhard, G.: Böden der Welt, 2, Springer Spektrum Verlag, Berlin Heidelberg, Germany, 2014.

555 Zech, W. and Wilke, B.: Vorläufige Ergebnisse einer Bodenchronosequenzstudie im Zillertal, Mitteilungen der Deutschen Bodenkundlichen Gesellschaft, 25 (1), 571-586, 1977. 
Table 1: Overview over all soil profiles, soil and modern faeces samples from the prehistorical encampment site of Ullafelsen in the Fotsch Valley, Stubai Alps (Austria). Analytical results of TOC, TN and TOC/N are presented.

\begin{tabular}{|c|c|c|c|c|c|c|c|}
\hline Soil profile & $\begin{array}{c}\text { Altitude } \\
\text { [m a.s.I.] }\end{array}$ & Soil profile coordinates & Sample no. & Soil horizon & TOC [\%] & TN [\%] & $\mathrm{TOC} / \mathrm{N}$ \\
\hline \multirow{7}{*}{$1.1 \mathrm{C} 4 \mathrm{w}$} & \multirow{7}{*}{1869} & \multirow{7}{*}{$\mathrm{N} 47.14702^{\circ} \mathrm{E} 11.21475^{\circ}$} & 1 & OAh1 & 15.1 & 0.8 & 20.0 \\
\hline & & & 2 & OAh2 & 8.5 & 0.3 & 24.6 \\
\hline & & & 3 & OAh3 & 4.3 & 0.1 & 33.8 \\
\hline & & & 4 & $E(L L)$ & 3.2 & 0.1 & 25.0 \\
\hline & & & 5 & $\mathrm{Bh}$ & 8.3 & 0.3 & 28.1 \\
\hline & & & 6 & Bs & 1.6 & 0.1 & 24.4 \\
\hline & & & 7 & $\mathrm{BvCv}$ & 0.8 & 0.0 & 17.9 \\
\hline \multirow{5}{*}{$1.1 \mathrm{~B} 5 \mathrm{~s}$} & \multirow{5}{*}{1869} & \multirow{5}{*}{$\mathrm{N} 47.14704^{\circ} \mathrm{E} 11.21474^{\circ}$} & 8 & OAh1 & 10.3 & 0.6 & 17.9 \\
\hline & & & 9 & $E(L L)$ & 3.3 & 0.1 & 22.5 \\
\hline & & & 10 & $\mathrm{Bh}$ & 6.4 & 0.2 & 26.8 \\
\hline & & & 11 & Bs & 2.2 & 0.1 & 24.5 \\
\hline & & & 12 & $\mathrm{BvCv}$ & 0.3 & 0.0 & 12.4 \\
\hline \multirow{5}{*}{ 1.1 B5w } & \multirow{5}{*}{1869} & \multirow{5}{*}{$\mathrm{N} 47.14703^{\circ} \mathrm{E} 11.21474^{\circ}$} & 13 & OAh1 & 18.2 & 1.0 & 18.0 \\
\hline & & & 14 & $E(L L)$ & 4.5 & 0.1 & 37.2 \\
\hline & & & 15 & $\mathrm{Bh}$ & 6.1 & 0.2 & 28.3 \\
\hline & & & 16 & Bs & 2.3 & 0.1 & 27.2 \\
\hline & & & 17 & $\mathrm{BvCv}$ & 0.7 & 0.0 & 16.2 \\
\hline \multirow{5}{*}{$1.1 \mathrm{G} 5 \mathrm{n}$} & \multirow{5}{*}{1869} & \multirow{5}{*}{$\mathrm{N} 47.14704^{\circ} \mathrm{E} 11.21482^{\circ}$} & 18 & OAh1 & 14.2 & 0.7 & 18.9 \\
\hline & & & 19 & OAh2 & 8.4 & 0.3 & 26.5 \\
\hline & & & 20 & OAh3 & 25.0 & 0.9 & 28.4 \\
\hline & & & 21 & $E(L L)$ & 3.3 & 0.1 & 25.2 \\
\hline & & & 22 & $\mathrm{Bh}$ & 7.1 & 0.3 & 26.8 \\
\hline \multirow{7}{*}{$1.9 \mathrm{NW}$} & \multirow{7}{*}{1867} & \multirow{7}{*}{ N $47.14698^{\circ}$ E $11.21492^{\circ}$} & 23 & OAh1 & 19.3 & 1.2 & 16.7 \\
\hline & & & 24 & OAh2 & 12.5 & 0.7 & 18.6 \\
\hline & & & 25 & OAh3 & 28.8 & 1.0 & 27.7 \\
\hline & & & 26 & $E(L L)$ & 2.5 & 0.1 & 19.5 \\
\hline & & & 27 & $\mathrm{Bh}$ & 4.8 & 0.2 & 24.9 \\
\hline & & & 28 & Bs & 2.5 & 0.1 & 27.1 \\
\hline & & & 29 & $\mathrm{BvCv}$ & 1.6 & 0.1 & 26.8 \\
\hline \multirow{7}{*}{ 1.9 NE } & \multirow{7}{*}{1867} & \multirow{7}{*}{$\mathrm{N} 47.14699^{\circ} \mathrm{E} 11.21494^{\circ}$} & 30 & OAh1 & 13.6 & 0.7 & 18.5 \\
\hline & & & 31 & OAh2 & 11.9 & 0.5 & 21.7 \\
\hline & & & 32 & E 1 (LL) & 4.3 & 0.2 & 28.3 \\
\hline & & & 33 & $\mathrm{Bh}$ & 5.5 & 0.2 & 23.1 \\
\hline & & & 34 & Bs & 3.6 & 0.1 & 27.8 \\
\hline & & & 35 & E 2 (LL) & 1.3 & 0.1 & 23.6 \\
\hline & & & 36 & $\mathrm{BvCv}$ & 2.1 & 0.1 & 27.1 \\
\hline $1.9 \mathrm{SW}$ & 1867 & $\mathrm{~N} 47.14698^{\circ} \mathrm{E} 11.21493^{\circ}$ & 37 & $E(L L)$ & 1.3 & 0.1 & 16.9 \\
\hline Faeces I & Cattle & & 38 & & 43.5 & 3.0 & 14.5 \\
\hline Faeces II & Sheep & & 39 & & 42.6 & 2.3 & 18.4 \\
\hline
\end{tabular}


https://doi.org/10.5194/bg-2021-186

Preprint. Discussion started: 22 July 2021

(c) Author(s) 2021. CC BY 4.0 License.
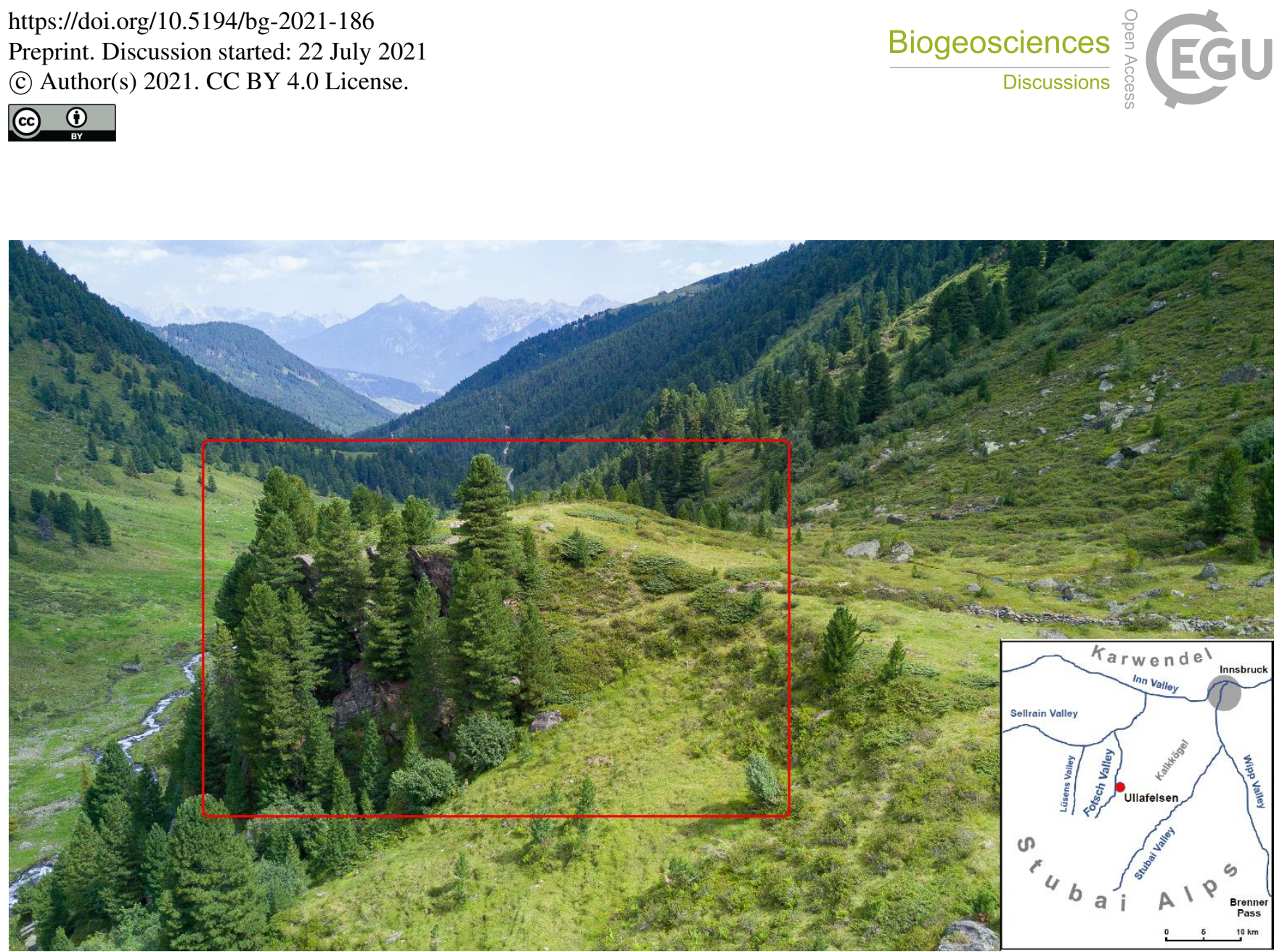

Figure 1: The prehistorical encampment site of Ullafelsen in the Fotsch Valley, Stubai Alps, southwest of Innsbruck, Tyrol (Austria). Northward view from the inner Fotsch Valley over the Ullafelsen (1869 $\mathrm{m}$ a.s.l.) to the Karwendel mountain range in the Northern Limestone Alps (Photo: E. Hüsing, 2018).

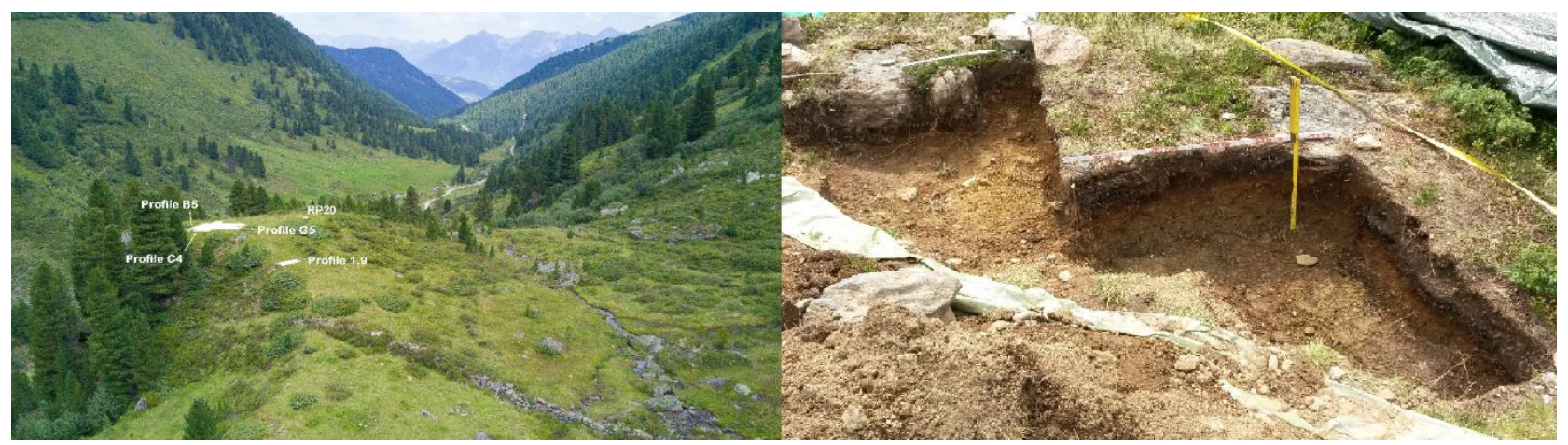

Figure 2: Left: NNW view over the Ullafelsen in the Fotsch Valley, Stubai Alps (Austria) at the upper timberline. The geoarchaeological excavation area on the Ullafelsen plateau with the reopened and sampled soil profiles $1.1 \mathrm{B5}$, $1.1 \mathrm{C} 4$ and $1.1 \mathrm{G5}$ and the newly opened and sampled soil profile 1.9 several meters towards the southeast are shown. Right: Reopened archaeological excavation area. View to the southwestern part of the sampled soil profiles (from Zech et al., 2021). 
https://doi.org/10.5194/bg-2021-186

Preprint. Discussion started: 22 July 2021

(c) Author(s) 2021. CC BY 4.0 License.
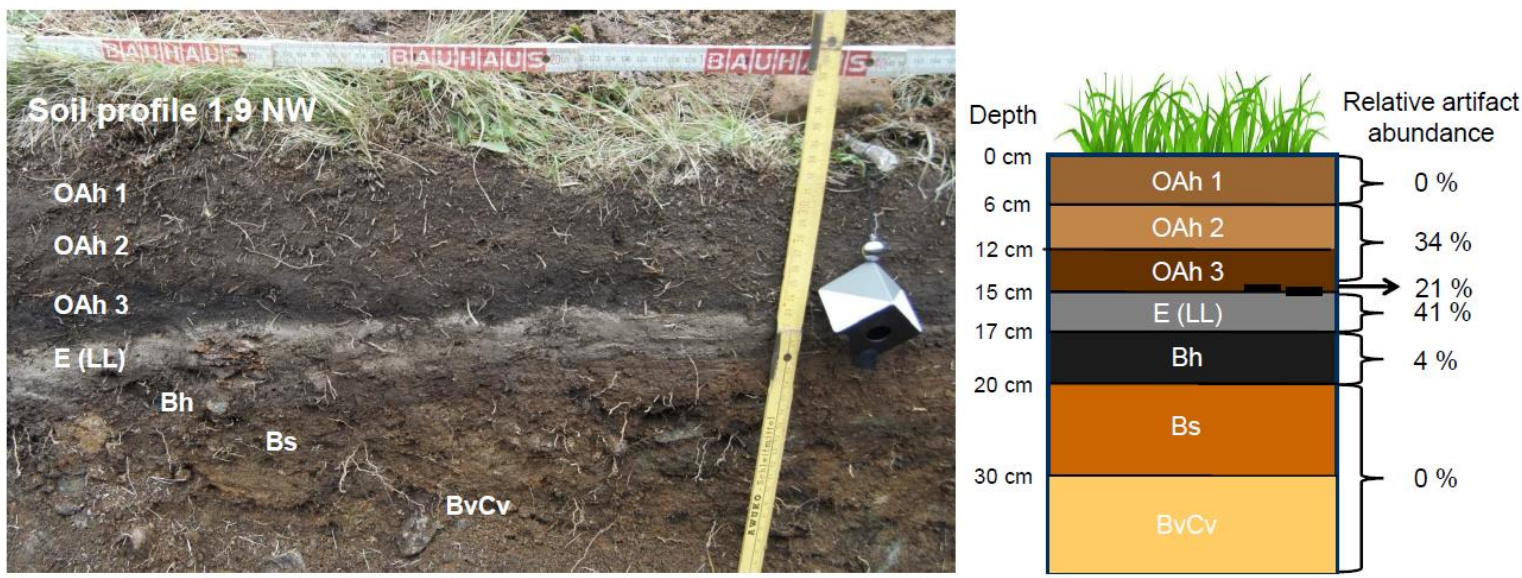

Figure 3: Left: Soil profile 1.9 NW, which represents a typical soil profile for the Ullafelsen in the Fotsch Valley, Stubai Alps (Austria). Right: Schematic horizons of the soil profiles on the Ullafelsen. Note that the soil profiles reveal a high heterogeneity. Nevertheless, the soil horizons OAh3 and Bh are characterized by a humus-enrichment. The E (LL) horizon ("light layer") reveals the highest relative artifact abundance $(\sim 41 \%)$ and is overlain by several fireplaces on the Ullafelsen. This horizon is considered as living floor of the Mesolithic hunter-gatherers (Geitner et al., 2011; Geitner et al., 2014). Due to TOC content partly $\geq 15 \%$, we adopted the soil horizon classification by Zech et al. (2021).
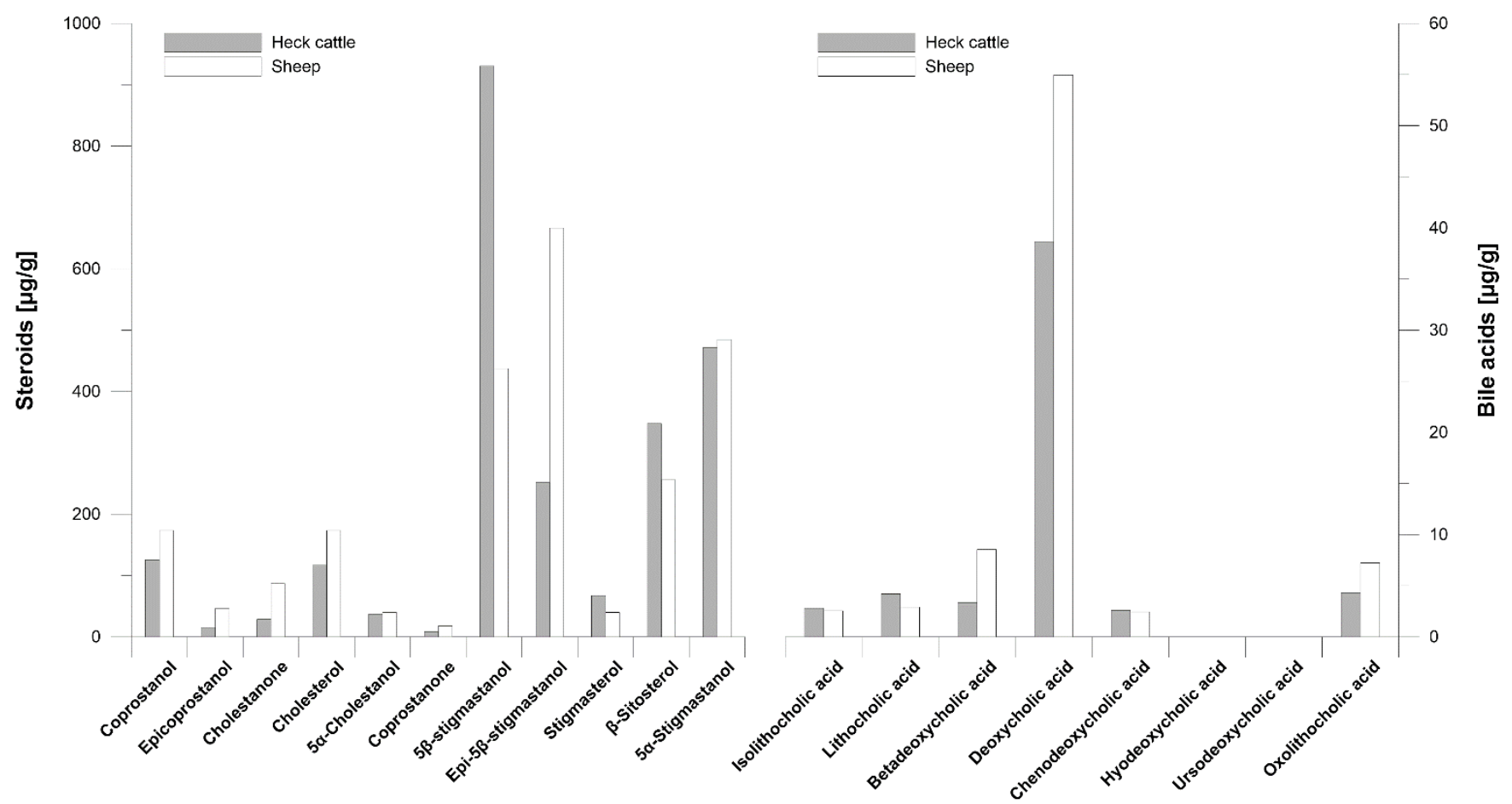

580 Figure 4: Biomarker patterns of modern faeces from predominating animals at the prehistorical encampment site of Ullafelsen in the Fotsch Valley, Stubai Alps (Austria) and surroundings. Steroid and bile acid contents of cattle and sheep faeces are given in $\mu \mathrm{g} / \mathrm{g}$ dry matter. 
https://doi.org/10.5194/bg-2021-186

Preprint. Discussion started: 22 July 2021

(c) Author(s) 2021. CC BY 4.0 License.

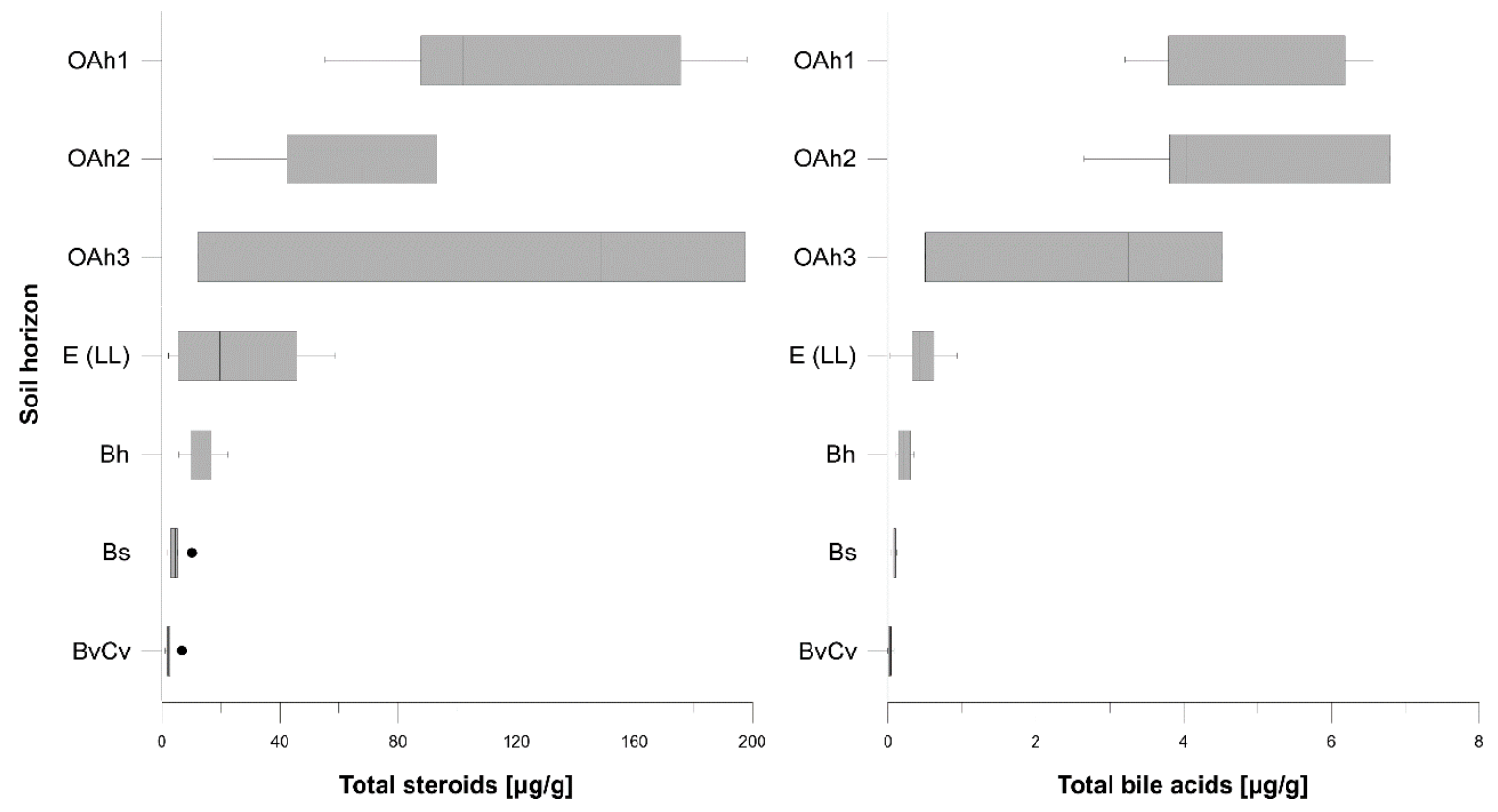

Figure 5: Box plots illustrating the total steroid and bile acid contents (in $\mu \mathrm{g} / \mathrm{g}$ dry matter) of the investigated soil profiles from the prehistorical encampment site of Ullafelsen in the Fotsch Valley, Stubai Alps (Austria), categorized by the soil horizons OAh1 (n=6), OAh2 $(n=4)$, OAh3 $(n=3), E(L L)(n=8)$, Bh $(n=6)$, Bs $(n=5)$ and BvCv $(n=5)$.

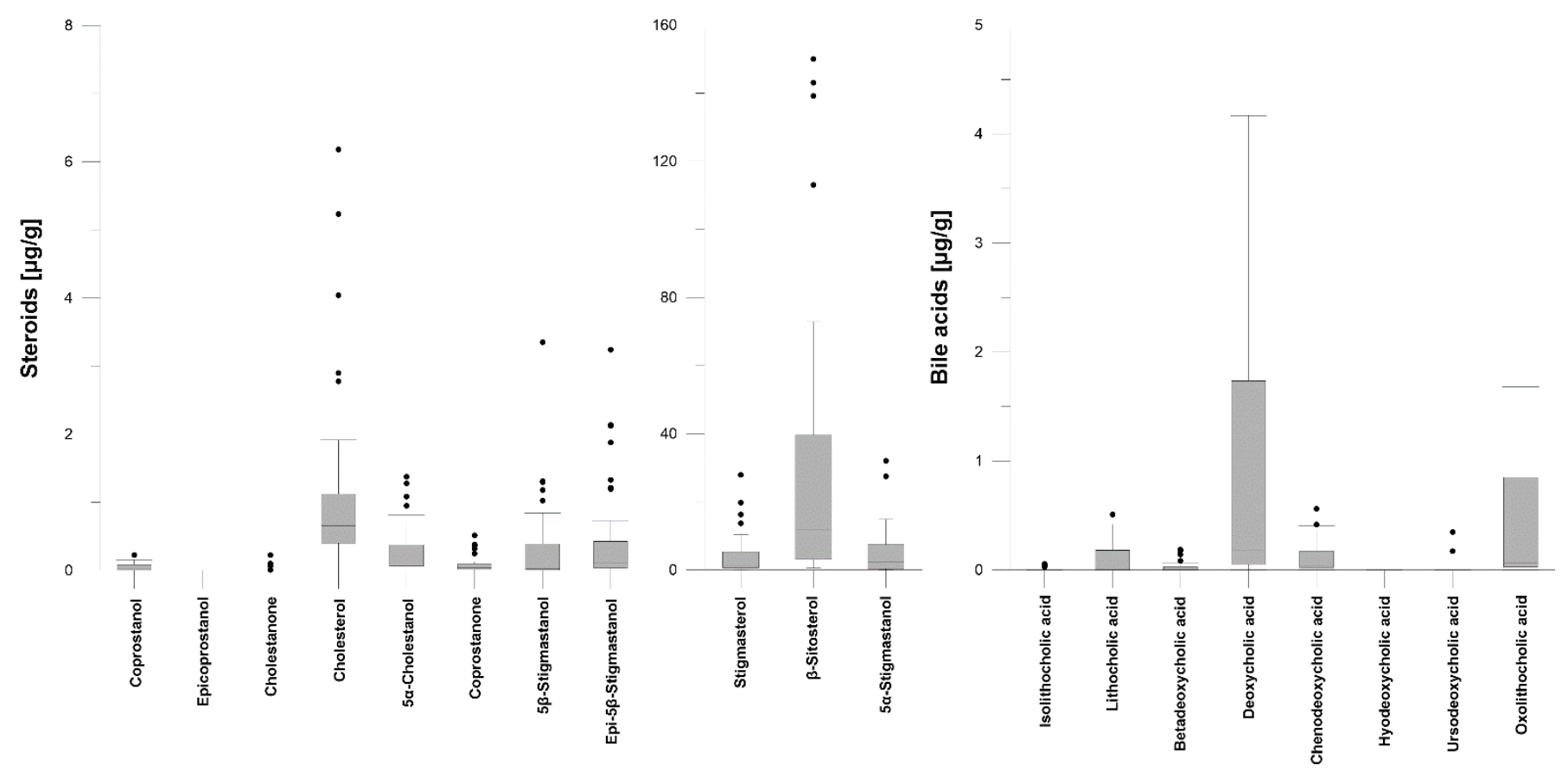

Figure 6: Box plots visualizing the content (in $\mu \mathrm{g} / \mathrm{g}$ dry matter) of steroid and bile acid patterns for all soil samples from the prehistorical encampment site of Ullafelsen in the Fotsch Valley, Stubai Alps (Austria). For a better overview, the steroids stigmastanol, $\beta$-sitosterol and $5 \alpha$-stigmastanol were plotted to a separate $y$-axis because of the high steroid contents. 
https://doi.org/10.5194/bg-2021-186

Preprint. Discussion started: 22 July 2021

(c) Author(s) 2021. CC BY 4.0 License.

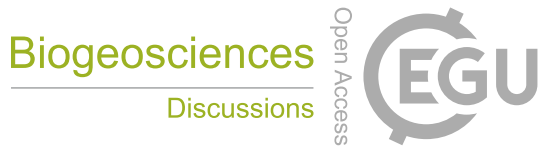

(c) (1)

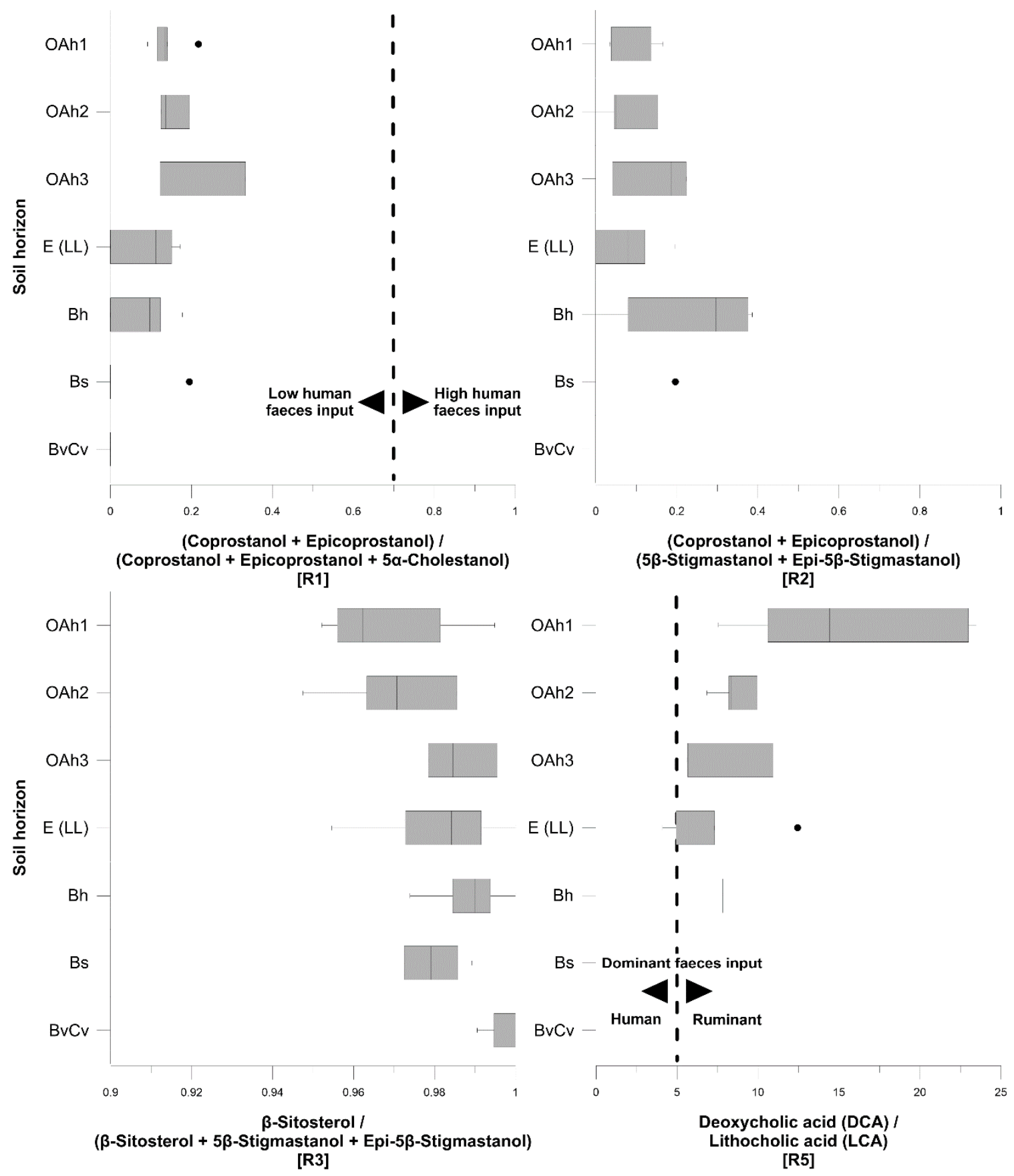

Figure 7: Box plots indicating steroid and bile acid ratios for estimating the origin of faecal matter. Ratio 1 describes the input of human faeces in soils, whereas ratio 2 and ratio 5 determine the input of human vs. ruminant faeces. Thresholds ratio 1: ratios $<0.7$ assume low human faeces input, ratios $>0.7$ show high human faeces input. Thresholds ratio 5 : ratios $<5$ point to a dominant human faeces input, ratios $>5$ represent a dominant ruminant faeces input. Ratio 3 considers the input of $\beta$-sitosterol as plant-derived steroid. 
https://doi.org/10.5194/bg-2021-186

Preprint. Discussion started: 22 July 2021

(c) Author(s) 2021. CC BY 4.0 License.

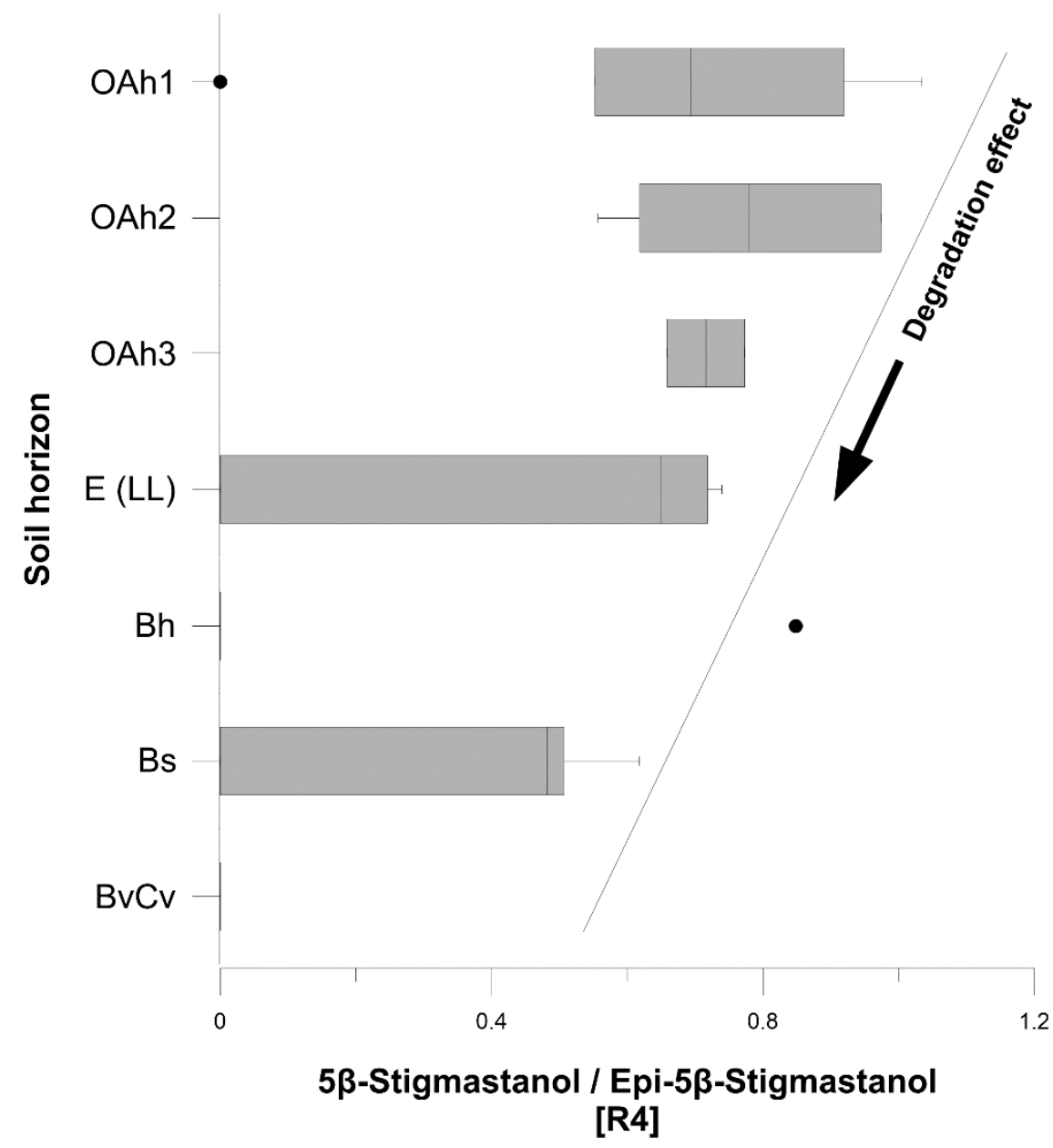

Figure 8: Microbial transformation of $5 \beta$-stigmastanol to epi-5 $\beta$-stigmstanol (Ratio 4). Epimerization of steroids ("Degradation effect") takes place over time due to microbial processes in soils (Bull et al., 2001; Prost et al., 2017). 